\title{
Survey of Nunavut Post-Secondary Students: \\ Determinants of School Completion, Post-Secondary Education, and Education Success
}

Moriah Sallaffie

Qaujigiartiit Health Research Centre

Maria Cherba

University of Ottawa

Gwen K. Healey Akearok

Qaujigiartiit Health Research Centre

Jessica Penney

Qaujigiartiit Health Research Centre 


\begin{abstract}
Little is known about Nunavut students' experiences in high school and post-secondary education, in particular their self-defined determinants of success. This study aimed to understand factors that influence secondary school completion, post-secondary education, and education success for students from Nunavut. An online survey was conducted with 91 current post-secondary students in 2018-19. Results found that students articulated complex support needs that influence their success, with roles for parents, teachers, and the community. Students identified support needs gaps, primarily in the form of funding distribution and delivery. Recommendations include increased financial, counselling, and mental health support for Nunavut students.
\end{abstract}

Keywords: Inuit education, Nunavut education, Indigenous post-secondary students

\title{
Résumé
}

On en sait peu sur l'expérience des étudiants du Nunavut du secondaire et du postsecondaire, particulièrement en ce qui concerne les facteurs de réussite qu'ils ont eux-mêmes déterminés. Cette étude vise à comprendre les facteurs qui influencent l'obtention du diplôme d'études secondaires, l'éducation postsecondaire et la réussite scolaire des élèves du Nunavut. Un sondage en ligne a été mené auprès de 91 étudiants de niveau postsecondaire en 2018-19. Les résultats ont révélé que les élèves expriment des besoins de soutien complexes qui influencent leur réussite; les parents, les enseignants et la communauté ayant tous un rôle à jouer. Les élèves ont identifié des lacunes en matière de soutien, principalement liées à la répartition et à la distribution du financement. Les recommandations comprennent un soutien accru en matière de financement, de counseling et d'aide en santé mentale pour les étudiants du Nunavut.

Mots-clés : éducation chez les Inuits, éducation au Nunavut, étudiants autochtones de niveau postsecondaire 


\section{Introduction}

Educational success is a topical issue in Nunavut, the youngest territory in Canada, established in 1999 and one of four Inuit regions in the country. Nunavut's relatively recent existence means legislation and policy have historically been borrowed from other jurisdictions and are regularly being updated and amended (McGregor, 2012). This does not come without its challenges. For example, Bill 25, an act to replace the Education Act and the Inuit Language Protection Act, has been highly criticized for its Inuit language adjustments by the public, community organizations, and Nunavut Tunngavik Incorporated (the organization representing Nunavut Inuit) (Nunavut Tunngavik Incorporated, 2019). The current increased level of discussion and state of flux around education in Nunavut means locally driven research is important for monitoring and contributing to the discussion and evidence-based decision making.

Nunavut was created in April 1999 through the establishment of the Nunavut Act and Nunavut Land Claims Agreement, the largest Indigenous land claims agreement in Canadian history (Government of Canada, 1993). It is also geographically the largest of the Canadian provinces and territories, consisting of approximately $20 \%$ of Canada's land mass. In the 2016 Canadian census, Nunavut had a population of 35,944 people. It is a majority-Inuit region, with 30,135 people identifying as Inuit and 22,600 people identifying Inuktut, the Inuit languages, as their mother tongue (Statistics Canada, 2017b).

Education in Nunavut is delivered by the territorial Government of Nunavut and local District Education Authorities (DEAs). The predominance of Inuit language and culture is seen in the territorial government's mandates, policies, and services, including within education provision. Inuit Qaujimajatuqangit (IQ), or Inuit knowledge and societal values, are promoted and integrated into the government structure, including through a framework called Iviqtippalliajut: In the Process of Falling into Place, which intends to "bridge the principles of public government and Inuit societal values" (Government of Nunavut, 2018, p. 3). In the education context, the Department of Education has an Inuit Qaujimajatuqangit Education Framework and other guiding documents that aim to position Inuit knowledge and values as the foundation for curriculum in Nunavut (Nunavut Department of Education, 2007).

This study was part of a multi-year, mixed methods research project studying education determinants in Nunavut in partnership with the Coalition of Nunavut District 
Education Authorities, the Aqquimavvik Society, and partners at Laval University. The goal of the research project was to explore the determinants of secondary school completion and post-secondary education for Nunavut students. The next section of this article outlines existing literature on secondary and post-secondary education in Nunavut, with a focus on student perspectives.

\section{Secondary and Post-Secondary Education in Nunavut}

\section{Education Context}

There is extensive literature on Inuit education in Nunavut and Inuit Nunangat, ${ }^{1}$ the Inuit homelands in Canada, more generally. Within this literature, there is markedly more of a focus on primary and secondary school than on post-secondary education. This may be due to a lack of post-secondary education facilities and programs in Nunavut and Inuit Nunangat. There are no universities in any of the four Inuit regions in Canada. Nunavut Territory is home to Nunavut Arctic College (NAC), and a few university courses delivered in collaboration between NAC and southern universities. For example, a law program delivered jointly between NAC and the University of Saskatchewan, a nursing program delivered by NAC and Dalhousie University, and the Nunavut Teacher Education Program (NTEP) delivered with Memorial University of Newfoundland. To participate in other programs, especially graduate education programs, students must usually relocate to other parts of Canada, often to southern cities such as Ottawa, Montréal, Winnipeg, and Edmonton.

At the elementary and secondary school levels, there has been a concerted effort by the Government of Nunavut's Department of Education to integrate Inuit Qaujimajatuqnagit in the curriculum and education more generally. Nunavut has historically borrowed parts of curricula from other jurisdictions, such as Alberta, with adaptation and additions, though capacity to create a made-in-Nunavut curriculum is increasing. In a review of curriculum development documents from 1989, 1996, and 2007, McGregor

1 The term Inuit Nunangat comprises the four Inuit regions in Canada: the Inuvialuit Settlement Region, Nunavut, Nunavik, and Nunatsiavut. 
(2012) found that over time, legislation has been created to ensure Nunavut schools have curriculum and pedagogy in line with Inuit Qaujimajatuqangit. There has been a longterm government commitment to develop curriculum with Elders and based on Inuit foundations, as exhibited by the aforementioned Inuit Qaujimajatuqangit Education Framework.

Despite the formal acknowledgement of the need for Inuit culture, language, and worldviews in education (Government of Nunavut, 2018; McGregor, 2012; Nunavut Department of Education, 2007), graduation and post-secondary attendance continues to be challenging. In the 2016 Canadian census, only $47.8 \%$ of people aged 25 to 64 in Nunavut had a high school diploma or equivalency certificate, versus $86.3 \%$ of the general Canadian population (Statistics Canada, 2017b). These inequalities are in part due to Nunavut's unique context as a relatively newly established territory still developing its education sector, and the history of education in the region. Historical and current colonial challenges also remain in Nunavut (Aylward, 2007, 2009; Berger, 2006). Berger (2006) explains this as a result of Eurocentrism on the individual (teacher), systemic (educational system), and general Canadian levels. In addition, research by Aylward (2009) with non-Inuit teachers in Nunavut found that some teachers believe incompatibilities exist between Inuit cultural competencies and academic competencies, and that Inuit perspectives on child development may be misunderstood in the academic context.

Despite efforts such as the Nunavut Master of Education program, most teachers in Nunavut are non-Inuit, and the implementation of bilingual education is considered insufficient, with significant room for improvement (Anoee et al., 2017; Aylward, 2010). Teachers also feel unprepared or under-resourced to implement culturally relevant programs. Ultimately, Nunavut education is often an intercultural experience for primarily Inuit students and typically non-Inuit educators (Aylward, 2009). This is particularly true in high school, as education programs in Nunavut have tended to focus on training teachers for primary and elementary levels (Nunavut Arctic College, n.d.). To address the disconnect between intentions and implementation of Inuit Qaujimajatuqangit in Nunavut education, McGregor (2012) recommended better articulation of values and implementation from staff, leadership, and mentorship. Other research suggests a holistic approach could improve educational outcomes. Aylward (2004) writes: 
The person, language, culture, and environment cannot be separated and academically addressed as individual pieces. Having Inuit Qaujimajatuqangit be the lens through which we view all educational efforts necessitates a realization that the learning process is sustained through connections to community values, beliefs and practices. (p. 2)

\section{Previous Research on Student Perspectives}

Some research exists on student perspectives of various aspects of their educational experiences attending secondary school in Nunavut. At the high school level, in interviews with 19 youth, Walton et al. (2014) identified three areas of support noted by Nunavut students to create meaningful learning environments: personal supports promoting well-being and identity, cultural supports to strengthen Inuit language and culture, and educational supports specific to students' individual life goals and academic skills.

At the post-secondary level, research has investigated Inuit students' experiences of post-secondary education in the south. In interviews, focus groups, and workshops, it was found that key contributing factors for success included support, a strong high school background, and previous work and life experience (Rodon et al., 2015). Aspects of their post-secondary experiences that were highly valued included: having an instructor with knowledge of the North, having fellow students to share experiences with, and having academic, family, and employer support (Rodon et al., 2015).

Due to the unique geographic location of Nunavut and limited post-secondary institutions, especially for university courses, creative solutions are sometimes sought. For example, the Nunavut Master of Education program, a blended face-to-face and distance-learning program offered from 2006-13, included an online component called the Knowledge Forum (Wheatley et al., 2015). This online environment was considered necessary for distance learning and created a space where students could learn from each other (McAuley \& Walton, 2011). However, internet issues in Nunavut were a hindrance. The Nunavut context can require unique workarounds for post-secondary program delivery, and (even with innovations) can be limited by infrastructure issues. Despite this, the Knowledge Forum was considered positive and essential by students.

While this information on educational efforts and staff and student perspectives is helpful, there remains a knowledge gap around student-identified determinants of 
educational success, particularly at the post-secondary level. This research aims to close this gap through a survey with post-secondary education students from Nunavut studying within and outside their communities. In contrast with other studies focusing solely on Inuit, youth, or students based in certain geographic regions, this research project took a broad view with no gender, ethnicity, age, or type of post-secondary education limitations for participants.

The present study was undertaken at the request of communities and district education authorities in Nunavut, to implement a holistic approach to understanding secondary and post-secondary determinants of success, specifically examining student perspectives on their self-identified support needs to inform future educational initiatives in Nunavut.

\section{Methods}

This project followed the Piliriqatigiinniq Community Health Research Partnership Model, developed by Qaujigiartiit Health Research Centre in response to a community-identified need for research that responds to the priorities of Nunavummiut. In the Piliriqatigiinniq Model, research is collected, analyzed, and disseminated in a holistic and collaborative way (Healey \& Tagak, 2014). The approach also contributes to strengthening capacity and acknowledges the importance of Western and Inuit ways of knowing in addressing health concerns in Nunavut. It aims to generate knowledge that helps create healthy Nunavut communities.

In this study, an online survey was developed with employees of the Labour Market Division of the Government of Nunavut Department of Family Services, which oversees the student financial assistance programs for students called Financial Assistance for Nunavut Students (FANS) and Adult Learning and Training Support (ALTS). The online survey was distributed via email by the Department of Family Services to all recipients of FANS and ALTS funding in the 2018-19 school year. This included students in university, college, trades, or any other eligible post-secondary program.

Survey questions focused on educational background, perspectives on success, transitions to post-secondary education, support sources, and desires. The survey consisted of 44 questions, including a mixture of multiple-choice and open-ended questions. 
This design allowed for statistical analysis, as well as for students to provide details about their experiences. One hundred and thirty-one responses were received during September 2018. Forty incomplete responses (answers to the first three questions or less) were disregarded, and 91 responses were retained for analysis. Descriptive statistics were conducted with SPSS and Excel. The next section of this article focuses on generalized survey results relating to demographic information, students' educational experiences, and their parents' educational backgrounds.

\section{Results}

\section{Participants Profile}

Sixty-two participants out of 91 shared basic demographic information. Of these 62 participants, 50 were female (55\%), 11 were male (12\%), and one was transgender. Their ages ranged from 17 to 48 years old (mean $=25.5)$. Fifty-five $(60 \%)$ participants identified as Inuit, with 12 of these also identifying with a second cultural group (such as White, Scottish, First Nations, European).

Information on spoken and written language abilities was also collected. Regarding spoken languages, 24.2\% mainly spoke English with Inuktut secondary, 17.6\% spoke English only, 11\% spoke mainly Inuktut with English secondary, 7.7\% spoke mainly English with French secondary, 4.4\% spoke Inuktut only, 3.3\% spoke another language, and the spoken languages of $31.9 \%$ were unknown. For written language abilities, $31.9 \%$ mainly wrote in English with Inuktut secondary, 25.3\% wrote in English only, 3.3\% mainly wrote in Inuktut with English secondary, 3.3\% wrote mainly in English with French secondary, 2.2\% wrote in Inuktut only, 2.2\% wrote in another language, and the written abilities of $31.9 \%$ were unknown (see Table 1). 


\section{Table 1}

Spoken and Written Language Abilities

\begin{tabular}{ccc}
\hline Language Abilities & $\begin{array}{c}\text { Spoken Percentage } \\
(\mathbf{\%})\end{array}$ & $\begin{array}{c}\text { Written Percentage } \\
\mathbf{( \% )}\end{array}$ \\
\hline English with Inuktut Secondary & 24.2 & 31.9 \\
English Only & 17.6 & 25.3 \\
Mainly Inuktut with English Secondary & 11 & 3.3 \\
English with French Secondary & 7.7 & 3.3 \\
Inuktut Only & 4.4 & 2.2 \\
Another Language & 3.3 & 2.2 \\
Unknown & 31.9 & 31.9 \\
\hline
\end{tabular}

Participants came from 16 different communities: Iqaluit (16\%), Arviat (10\%), Rankin Inlet (10\%), Gjoa Haven (5\%), Kugaaruk, Baker Lake, Cambridge Bay, Chesterfield Inlet, Clyde River, Coral Harbour, Igloolik, Panniqtuuq, Taloyoak, Arctic Bay, Hall Beach, and Pond Inlet. Fifty-seven (63\%) participants went to high school in their own community. The top three communities in which respondents had attended high school were Iqaluit (23.1\%), Rankin Inlet (17.6\%), and Arviat (16.5\%).

\section{Educational Experience}

Out of the 91 participants, most (57.1\%) had completed high school as their highest level of education, $30.8 \%$ had a college diploma, $6.6 \%$ had an undergraduate degree, $3.3 \%$ had completed junior high (up to Grade 8 ), and 2.2\% had a master's degree. At the time of responding to the survey, $42.9 \%$ of participants were working on a bachelor's degree, $37.4 \%$ on a high school diploma, $5.5 \%$ on an apprenticeship, $3.3 \%$ on a master's, $1.1 \%$ on a $\mathrm{PhD}$, and $9.9 \%$ selected "other" or did not answer. The top three areas of study or training were education (15.4\%), social sciences (11\%) and health sciences $(8.8 \%)$.

When asked, "Why did you choose to study in your current program?" (n=91), the top four answers (over 50\%), were "I like this topic and find it interesting" (56\%), “To prepare for a specific job or career" (52.7\%), "To gain life experience" (53.8\%), and "To develop skills" (51.6\%). Other common answers were, "To contribute to my community" (46.2\%), "To get a good education" (42.9\%), and "To get a good job" (41.8\%) (Figure 1). 


\section{Figure 1}

Student Reasons for Choosing Current Education Program

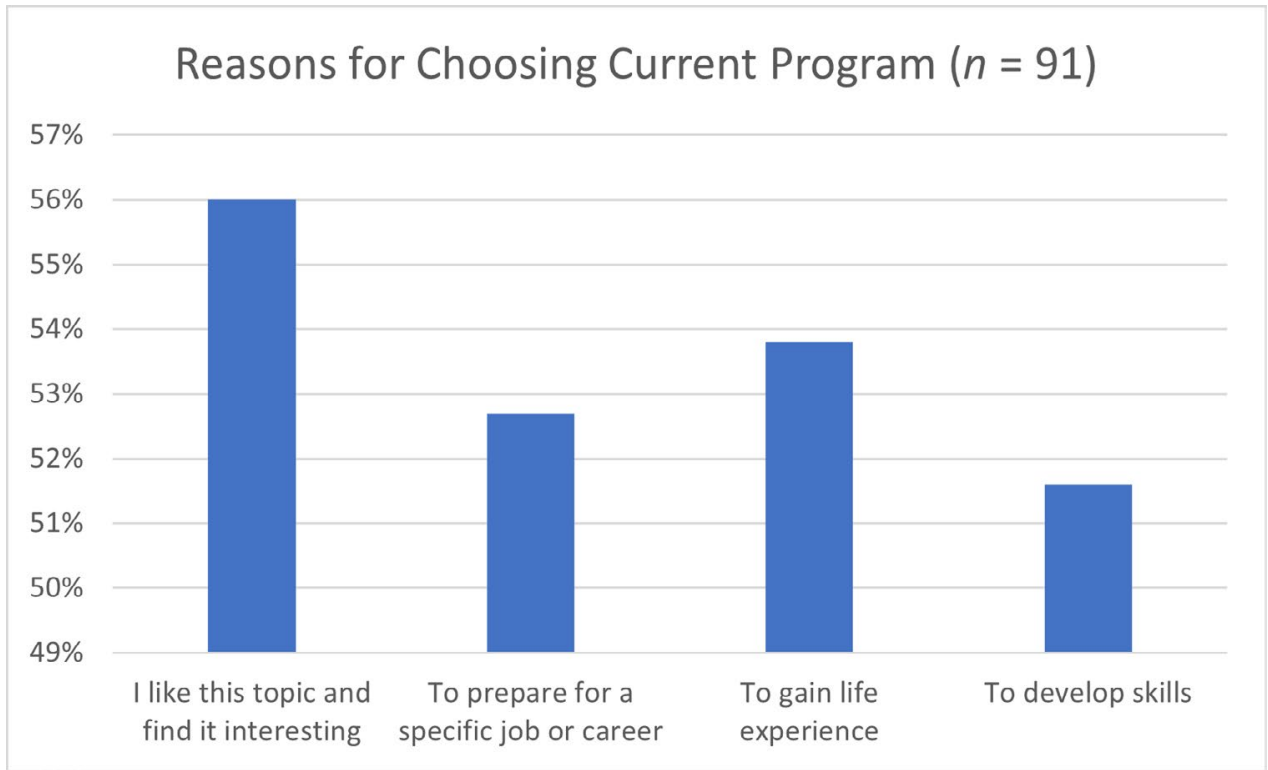

Given a choice, most students would prefer to study in their home community. Over half (61.5\%) said they would take the program they were taking in their home community, were it available ( $n=91), 20.9 \%$ said they would not, and 17.6\% said "Maybe." Twenty-one students provided reasons why they would not choose to stay in their home community. These reasons were generally related to enhanced resources or facilities available outside their home community (e.g., student housing and technical resources) and wanting to explore or experience living in a different environment. For example, one student specified, "I like learning in different environments and being able to have the best of both worlds, living in Nunavut and Ontario." When asked if they planned to stay or return to their community after completion of their schooling/training, $60.4 \%$ indicated "Yes," 30.8\% indicated "No," and 8.8\% said "Maybe" $(n=91)$.

\section{Parents/Guardians/Caregivers Education Experiences}

Forty-one percent of participants indicated that their parents, guardians, or caregivers attended residential school. Thirty-one percent responded that they did not, $22 \%$ did not 
know, and $2 \%$ did not answer $(n=91)$. When asked about the highest level of education that the two people who were most involved in raising them during childhood completed, $58 \%$ indicated that they did not know. Twelve percent indicated "Undergraduate degree," 10\% said "High school (Grade 12)," 10\% responded "Junior High (Grade 8)," 9\% said "College," and 1\% responded "Elementary" $(n=91)$ (Table 2). The history of residential schools in Northern Canada (including Nunavut) is unique due to geography and the Government of Canada's legislative and governing priorities during that era, as outlined by Volume 2 of the Truth and Reconciliation Commission (TRC). According to the TRC, the per capita impact of residential schools is believed to be higher in the North than anywhere else in Canada due to the high proportion of Indigenous residents (Truth and Reconciliation Commission of Canada, 2015).

Table 2

Parent/Guardian/Caregivers' Educational Attainment

\begin{tabular}{cc}
\hline Highest Level of Education & Percentage (\%) \\
\hline Undergraduate Degree & 12 \\
Junior High (Grade 8) & 10 \\
High School (Grade 12) & 10 \\
College & 9 \\
Elementary & 1 \\
Did Not Know & 58 \\
\hline
\end{tabular}

\section{Perspectives on Success}

Seventy-nine students answered an open-ended question about how they envision success in their education, future or current work, and personal life. Thematic analysis of the answers revealed five major themes: (1) Complete education and find a job in a chosen career (32\%); (2) work hard, have goals and achieve them, never give up (29\%); (3) contribute to the well-being of the community (23\%); (4) have a fulfilled and happy life (20\%); and (5) be a role model for their family, community, or society (19\%).

Many students identified education and career as key components in success, while others associated success with having a fulfilled and happy life. However, for many students the individual, family, community, and society aspects of success were 
interrelated. For example, one student wrote, "Making my family proud...means success. I hope to become a mental health counselor in my community once my education is complete and that will feel like success." This illustrates the interrelated nature of family and community success. Another wrote, "Knowing how to write and talk in Inuktitut and English in Nunavut is important, understanding our elders and youth to make Nunavut and everyone a better place/person." This student identifies how individual language ability has a beneficial impact on society as a whole.

\section{Success Transitioning to Post-Secondary}

Sixty-six students answered an open-ended question about the ways they feel they have been successful in adjusting to their new community and environment, including on an academic, social, and personal level. Examples of academic success in transitioning were being able to keep up with demands and deadlines, getting good grades, and participating in classes. Examples of personal level success in transitioning to post-secondary education were learning how to live independently (e.g., managing time and budgeting), learning how to live in the city, and building emotional skills (e.g., staying positive and asking for help).

Students also mentioned factors that made their adjustment to post-secondary education more difficult, including financial struggles, being away from family, a different school environment, a high academic workload, stigma and judgement, and mental health concerns. Factors that helped contribute to adjustment to post-secondary included being supported by others (e.g., friends, family, and instructors), financial and academic support, being able to ask for help, extracurricular activities, familiarity with the university, strong academic skills, studying at home, and having lived outside of the home or alone before. One student mentioned how experimentation and experience over time helped them adjust, writing, "As the first year progressed, I learned how to strategize to see what works and what doesn't." These findings suggest that it takes time to transition successfully from secondary to post-secondary education, in addition to other support needs.

\section{Coping with Stress, Adversity, and Resilience}

Almost half (42.9\%) of students expressed that they feel stressed attending their post-secondary programs "sometimes" or "a lot," 9.9\% either "don't feel stressed at all" or "don't 
really feel stressed," $14.3 \%$ had not noticed or thought about it, and 33\% did not answer this question. Students had many suggestions for ways that their academic career could be made less stressful. The most common suggestion by a large margin was increased funding support (77.2\%), with the next most common suggestion being post-secondary programs available in their home communities (38.6\%).

Sixty-two students answered a question about events that occurred during high school that they felt impacted their school success. A thematic analysis of 43 answers from students who felt an occurrence did impact their success revealed two main themes: loss of a loved one (not due to suicide) $(n=10)$ and mental health problems $(n=9)$, including suicidal thoughts $(n=2)$. Despite these challenges, 12 students explained how they overcame these events, displaying resilience. For example, one student shared, "In high school my anxiety disorder showed itself. Since then I have had to gain coping skills to deal with my anxious tendencies. These coping skills have been crucial in my success and dedication to my education and family."

\section{Support Systems}

Students identified complex ideal support systems with roles for parents and caregivers, the general community, and teachers/school staff in high school and during post-secondary education. Sixty-four students answered an open-ended question about the support that they received from their parents/caregivers, with 57 students saying that they felt they received enough support. Forms of support included being encouraged to study, being taught the importance of education, a safe home environment, and help with homework. This was not universal though, and 17 students identified ways their parents/caregivers could have provided more support, such as better mental health support and more educational resources. Some students also acknowledged that their parents were dealing with their own mental health and addictions issues, with one sharing, "I wish my mom could have helped herself, or have felt comfortable with helping herself mentally and emotionally."

Sixty-two students answered an open-ended question about the support they received from their community. Forty-seven students said that they felt they were supported by the community, and teachers were cited as the most frequent example of people who had supported them. Other supportive community members who were mentioned 
included: counsellors, social workers, friends, employers, and family members other than parents/caregivers (e.g., grandparents, siblings). When asked what other kinds of support participants would have appreciated in high school, the most frequent answers were related to better access to mental health supports, better academic supports, and more access to student services.

There were diverse ways in which teachers were and were not supportive and encouraging. Sixty-one students answered a question about whether their student-teacher relationships were positive and encouraging, with $62 \%$ saying yes, $10 \%$ saying no, and $28 \%$ saying it depended on the teacher. Common ways teachers were supportive and encouraging related to showing positivity, listening to students, and motivating them to pursue their education. In contrast, ways in which teachers were not supportive and encouraging were related to not being there to help students, being on short-term contacts, giving the impression they were teaching in Nunavut for the money, and even inappropriate teacher-student relationships. The varied supportive nature of teachers was explained by one student who mentioned, "It all depends on the teacher's attitude. One teacher can make me feel like a smart student and support me whereas other teachers made me feel uneducated and stupid."

\section{Analysis}

This section of this article considers some main themes from the research project, their significance, and how they relate to other existing literature. Support was a key theme for success in both high school and post-secondary education. Further, students are not immune to social issues in Nunavut, and challenges such as a lack of affordable housing, the cost of living, and mental health issues can be inhibitors of education success. Finally, students have important practical suggestions for policies and programming that could improve their educational experiences and success. This section ends with several of these student-led recommendations, focusing on financial and mental health support.

\section{Determinants of Secondary School Success}

One major determinant of educational success in high school was students' relationships with their families, communities, and teachers. These multifaceted support networks 
can act as a way to ensure students receive support from a variety of points. For example, some students explained that teachers supported them when their families did not or could not. One person stated, "If my mom was busy (which was all the time), I filled that void with my teachers' presence. I had one teacher who is very much into philosophy_I'm taking Intro to Philosophy right now." Teachers can have a long-lasting impact on their students' life trajectories. Other research on student support systems found that positive student-teacher relationships are central to positive school outcomes, though the best outcomes are associated with a combination of support from other groups (including parents and friends) (Rosenfeld et al., 2000), similar to support systems detailed by students in this study.

Despite this important role for educators, teacher retention and recruitment has been a struggle in Nunavut for many years. This issue was highlighted by students as impacting their high school experiences. One student explained, "The teachers who stayed for over 2 years I had a strong positive relationship with them. I had a hard time connecting with teachers who left in a year or less knowing the fact they are going to leave in a short amount of time." Students explained that they preferred their teachers be dedicated members of their community, with cultural knowledge.

The reasons for teachers leaving are individual and complex, but existing research suggests that teachers face systemic challenges that impact their ability to stay in the education sector in Nunavut. Non-Inuit teachers may struggle with lack of resources to implement important and desired cultural programming, even if they want to do so (Berger \& Epp, 2007). Inuit staff may also face challenges when trying to change the status quo. Aylward's (2009) research with Inuit curriculum authors found that they were faced with non-Inuit staff who were hesitant to incorporate Inuit pedagogy. Despite a longstanding, multi-decade effort by the Department of Education to encourage Inuit ways of knowing in schools, as discussed by McGregor (2012), some teachers did not believe that Inuit culture had a place in schools.

It is also important to note that having supportive teachers was not a universal experience in high school. One respondent shared, "I never recalled anyone other than family supporting [me]." Several students shared experiences in which teachers were explicitly unsupportive, and one even noted that their teacher had a "colonial mindset." This parallels Berger's (2009) assertion of individual Eurocentrism hindering Nunavut's education system. He suggests that Eurocentrism has allowed the Western-dominant 
education status quo to remain in Nunavut, preventing an environment in which Inuit ways and values can thrive and transform the education system. In the case of teachers being unsupportive, other people may be an important support for students, further reinforcing the necessity of multifaceted support systems for students in Nunavut who are educated in a system that faces exceptional challenges.

The resistance to incorporating Inuit culture and language in the education system and a revolving door of non-Inuit teachers are alarming considering students in this research emphasized the important role of Inuit culture in their lives and education. When asked about anything they felt would have helped them be successful in meeting their educational goals, one student suggested:

Inuit-run programs that focus on building up specifically Inuit success... There are many capable Inuit that could contribute so much to this world but they are not given a chance to because there is so much ignorance and broken systems that need repairing.

Valuing and centring Inuit culture and ways of knowing is also essential considering its role in well-being and happiness. A study with Nunavut Inuit, including a youth component, by Kral et al. (2011) found that three themes are central to well-being: the family, talking/communication, and traditional Inuit culture and practices.

\section{Determinants of Post-Secondary Success}

In addition to high school, students in this study also identified various levels of support as key determinants for post-secondary educational success. Community support was considered one of these determinants. One student said:

The people in my community... were really supportive of my decision to pursue nursing. A number of them would constantly tell me that they are excited for me to become their nurse. They would also applaud the fact that I wanted to take a program in Iqaluit and learn about Arctic-based nursing.

There is pride and motivation associated with being supported by one's community. This is similar to Rodon et al.'s (2015) study with Inuit youth, in which support was considered a top contributing factor for success. Students describe success as a mixture 
of achieving personal goals and contributing to collective (community, family, societal) improvements.

Another consideration for post-secondary student success is how contemporary issues that affect the general Nunavut community also impact students. While family and community support are important for success, one of the reasons students said they would not choose to stay in their home community for education is that there is no student housing available. There is a chronic housing crisis in Inuit Nunangat, and 56.4\% of Inuit in Nunavut live in overcrowded homes (Statistics Canada, 2017a). According to Inuit Tapiriit Kanatami, the organization representing Inuit in Canada, Nunavut requires 3,500 housing units to eliminate the overcrowding gap, without factoring in population growth (Inuit Tapiriit Kanatami \& Government of Canada, 2019). A related issue is the cost of living in Nunavut, which is exponentially higher than other parts of Canada. This puts an extra strain on students, who often have a limited income.

\section{Solutions}

Students have concrete suggestions for policies that they feel would improve their educational success, particularly at the post-secondary level. Funding suggestions were a common theme, but other suggestions, connected to young peoples' academic, personal, and social development, were mentioned. This section will focus on suggestions for financial and mental health support.

Financial struggles were considered a factor that made the adjustment to post-secondary education more difficult. In particular, the amount of financial support received from government programs was widely considered to be insufficient, a source of stress, and even a reason why some students do not finish their post-secondary programs. One suggestion was to adjust the level of funding according to the living costs of where the student is attending post-secondary education. The insufficient financial support was directly connected to lack of progress on the Government of Nunavut's Inuit employment goals, as one student said:

We wonder why the representative level [of Inuit] within the public sector of [Nunavut] is so low; [it] is because where is the real financial support for post-secondary[?] Basically better off working as a cashier in Nunavut paying $\$ 60$ 
a month on rent than living below [the] poverty [line] in the south while you have no family or friends to help and guide you.

While the details in this particular example may be exaggerated due to frustration, a lack of financial support can compound the other struggles (such as loneliness and lack of guidance) that are associated with pursuing post-secondary education in the south.

Several answers in the survey directly mentioned how students believed counselling from high school guidance counsellors or other adults was or would have been beneficial to them in secondary school. Counselling was mentioned in the context of dealing with traumatic events and emotional issues. For example, as one student described, "I had a tough life, and for emotional support [it] would have been good if there was counselling. I had no idea how to cope with depressing situations, and the support would have helped out." Another student shared the following:

When it comes to emotional challenges, personally, I had the best support. Not from the employees of the school but from my own family/friends. Maybe consider hiring counsellors who will actually help the students in need rather than ones who [will] discourage students about themselves and their path toward their education, as that was my case with the guidance counsellor in my last high school.

For students who come from homes where, for a variety of complex reasons, emotional support may not be available, school-based counsellors could provide a level of support to allow them to be successful in secondary education and transitioning to post-secondary. This could act as a sort of safeguard for students. However, based on the demographics of Nunavut, the priorities of students in this study, and the existing literature, this support should be culturally relevant. Inuit culture and traditions and community-led programming are widely believed to be protective factors for Inuit mental health and wellness, including for youth (Gray et al., 2016; Healey et al., 2016).

The unique educational context in Nunavut means that students, particularly those living in southern Canadian cities, require distinctive supports, both in terms of finances and otherwise, to be successful in their educational goals. One student summarized this by contrasting the experiences for students living in the south versus those studying in the north:

I feel like there are not enough supports for students who attend in the south, both financially and for mental health. It's very difficult leaving and many students do 
not finish. But I feel like being away I notice the difference [in] treatment of students who go to school up north [than those] who go to school in the south.

Since students are often relocating for post-secondary programs, studying in the south is usually associated with living without family, friends, and community. Considering the aforementioned sections on the importance of these support systems, the requirement for many students to leave their homes for their chosen programs may lead to unequal experiences in post-secondary education.

Students also had suggestions for improving secondary student-teacher relationships; the most common was for teachers to get to know their students and the community, and to build relationships and trust by hiring teachers on longer contracts, facilitating opportunities for students and teachers to get to know each other outside the classroom, and helping teachers become more involved in the community. In addition, it was suggested that teachers be encouraged to learn Inuktitut. A concrete suggestion for building connections was to share food, with one person suggesting:

Maybe if they had more meal programs. A way students and teachers could get to know each other outside the classroom. I think if students could share food with teachers and saw the teachers interested in them they could start to build trust and relationships.

Sharing food is a common value in Inuit society related to kinship and social relations (Harder \& Wenzel, 2012; Wenzel, 1995), with community feasts being common events. Sharing food could be a culturally relevant way to improve the student-teacher relationship, and thus improve educational success.

\section{Discussion and Conclusions}

In addition to providing important information about educational success at multiple levels of schooling, this research contributes to the discussion around university studies in the North. Advocacy organizations and scholars have supported the establishment of a university in Inuit Nunangat for years (Inuit Tapiriit Kanatami, 2011; Rodon et al., 2014). This research also supports some of the arguments for a university, since, if given the chance, most Nunavut post-secondary students would choose to remain at home to 
undertake their studies. Further, students indicated that community support and that of others based in Nunavut (e.g., family and friends) who may be around if they did not have to leave the territory, is important to their success.

One of the strengths of this study is that it takes a holistic perspective on determinants of educational success in Nunavut, considering the roles of families, educators, and communities. This reflects the dynamics of life in Nunavut, which is highly relational. This research is also unique in its broad scope, considering all students from Nunavut, regardless of age, gender, ethnicity, and it surveyed students based in both northern and southern educational institutions.

However, it should be noted that the study is not ethnically representative of the population of Nunavut, which is almost $85 \%$ Inuit, as only $60 \%$ of respondents in this study identified as Inuk. Further, since the survey was only distributed to students currently enrolled in a post-secondary program, it only reached people who have been relatively successful in the Western academic sense, having completed high school and gone on to post-secondary studies. Future work could include the experiences of students who did not graduate or go on to study at a post-secondary level. The students surveyed in this work can comment on factors that would have improved their own experience, but their perspectives about what would have helped their peers are generally speculative.

Further, considering the importance put on financial issues and their relationship to stress, academic success, and completion of post-secondary programs, future work could involve evaluation of the financial support systems available to Nunavut students. The effectiveness of mental health supports available to students in secondary and post-secondary education are also potential areas for investigation. This research indicates that currently available structures are inadequate.

Overall, this research considered determinants of secondary and post-secondary educational success and support needs of students from Nunavut. It found that students require multi-level support from their families, educators, and communities. Students also identified solutions that would increase their success. At the secondary level, mental health supports such as counselling are not meeting student needs. At the post-secondary level, funding is considered insufficient and stress is exacerbated by housing and living costs. Future research could evaluate currently available programs to determine how they can meet students' needs better. 


\section{References}

Anoee, N. Q., Tulloch, S., Arreak-Kullualik, J., Wheatley, K., \& McAuley, S. (2017). (Re) Invigorating family and community leadership in Inuit bilingual education. AlterNative: An International Journal of Indigenous Peoples, 13(1), 2-10. https:// doi.org/10.1177\%2F1177180116689025

Aylward, M. L. (2004). Sivuniksamut Ilinniarniq: Future schools of Nunavut. Curriculum and school services. Nunavut Department of Education.

Aylward, M. L. (2007). Discourses of cultural relevance in Nunavut schooling. Journal of Research in Rural Education, 22(7), 1-9. https://jrre.psu.edu/sites/default/ files/2019-08/22-7.pdf

Aylward, M. L. (2009). Journey to Inuuqatigiit: Curriculum development for Nunavut education. Diaspora, Indigenous, and Minority Education, 3(3), 137-158. https:// doi.org/10.1080/15595690902991022

Aylward, M. L. (2010). The role of Inuit languages in Nunavut schooling: Nunavut teachers talk about bilingual education. Canadian Journal of Education, 33(2), 295-328. https://www.jstor.org/stable/canajeducrevucan.33.2.295

Berger, P. (2006). Some thoughts on Qallunaat teacher caring in Nunavut. Journal of Teaching and Learning, 4(2). https://doi.org/10.22329/jtl.v4i2.120

Berger, P. (2009). Eurocentric roadblocks to school change in Nunavut. Études/Inuit/ Studies, 33(1-2), 55-76. https://doi.org/10.7202/044960ar

Berger, P., \& Epp, J. R. (2007). “There's no book and there's no guide”: The expressed needs of Qallunaat educators in Nunavut. Brock Education: A Journal of Educational Research and Practice, 16(2). https://doi.org/10.26522/brocked. $\underline{\mathrm{V} 16 \mathrm{I} 2.86}$

Government of Canada. (1993). Nunavut Land Claims Agreement Act. https://laws-lois. justice.gc.ca/PDF/N-28.7.pdf

Government of Nunavut. (2018). Iviqtippalliajut: In the process of falling into place. https://www.gov.nu.ca/sites/default/files/ch__ iviqtippalliajut_report en_rev05. pdf 
Gray, A. P., Richer, F., \& Harper, S. (2016). Individual- and community-level determinants of Inuit youth mental wellness. Canadian Journal of Public Health, 107(3), e251-e257. https://doi.org/10.17269/cjph.107.5342

Harder, M. T., \& Wenzel, G. W. (2012). Inuit subsistence, social economy and food security in Clyde River, Nunavut. Arctic, 65(3), 305-318. http://pubs.aina. ucalgary.ca/arctic/Arctic65-3-305.pdf

Healey, G., Noah, J., \& Mearns, C. (2016). The eight ujarait (rocks) model: Supporting Inuit adolescent mental health with an intervention model based on Inuit ways of knowing. International Journal of Indigenous Health, 11(1), 92-110. https:// journals.uvic.ca/index.php/ijih/article/view/14394/6557

Healey, G., \& Tagak, A., Sr. (2014). PILIRIQATIGIINNIQ 'Working in a collaborative way for the common good.' International Journal of Critical Indigenous Studies, 7(1), 1-14. https://ijcis.qut.edu.au/article/view/117

Inuit Tapiriit Kanatami. (2011). First Canadians, Canadians first: National strategy on Inuit education 2011. https://www.tunngavik.com/files/2011/06/first-canadianscanadians-first-national-strategy-on-inuit-education-2011.pdf

Inuit Tapiriit Kanatami \& Government of Canada. (2019). Inuit Nunangat housing strategy. https://www.itk.ca/wp-content/uploads/2019/04/2019-Inuit-NunangatHousing-Strategy-English.pdf

Kral, M. J., Idlout, L., Minore, J. B., Dyck, R. J., \& Kirmayer, L. J. (2011). Unikkaartuit: Meanings of well-being, unhappiness, health, and community change among Inuit in Nunavut, Canada. American Journal of Community Psychology, 48(3-4), 426-438. https://doi.org/10.1007/s10464-011-9431-4

McAuley, A., \& Walton, F. (2011). Decolonizing cyberspace: Online support for the Nunavut MEd. The International Review of Research in Open and Distributed Learning, 12(4), 17-34. https://doi.org/10.19173/irrodl.v12i4.848

McGregor, H. (2012). Curriculum change in Nunavut: Towards Inuit Qaujimajatuqangit. McGill Journal of Education/Revue des sciences de l'éducation de McGill, 47(3), 285-302. https://mje.mcgill.ca/article/viewFile/8943/6828

Nunavut Arctic College. (n.d.). Programs: Education. https://arcticcollege.ca/education 
Nunavut Department of Education. (2007). Inuit Qaujimajatuqangit education framework. https://www.gov.nu.ca/sites/default/files/files/Inuit $\% 20$ Qaujimajatuqangit\%20ENG.pdf

Nunavut Tunngavik Incorporated. (2019, June 5). Bill 25 Education Act amendments disappoint again [Press release]. https://www.tunngavik.com/news/ bill-25-education-act-amendments-disappoint-again/

Rodon, T., Lévesque, F., \& Kennedy Dalseg, S. (2015). Qallunaaliaqtut: Inuit students' experiences of postsecondary education in the south. McGill Journal of Education/Revue des sciences de l'éducation de McGill, 50(1), 97-118. https:// doi.org/10.7202/1036108ar

Rodon, T., Walton, F., Abele, F., Kennedy Dalseg, S., O’Leary, D., \& Lévesque, F. (2014). Post-secondary education in Inuit Nunangat: Learning from past experiences \& listening to students' voices. Northern Public Affairs, 2, 70-75. http://www.northernpublicaffairs.ca/index/volume-2-special-issue-revitalizingeducation-in-inuit-nunangat/post-secondary-education-in-inuit-nunangat-learningfrom-past-experiences-listening-to-students-voices/

Rosenfeld, L. B., Richman, J. M., \& Bowen, G. L. (2000). Social support networks and school outcomes: The centrality of the teacher. Child and Adolescent Social Work Journal, 17(3), 205-226. https://doi.org/10.1023/A:1007535930286

Statistics Canada. (2017a). Census in brief: The housing conditions of Aboriginal people in Canada. https://www12.statcan.gc.ca/census-recensement/2016/as-sa/98-200$\underline{\mathrm{x} / 2016021 / 98-200-\mathrm{x} 2016021-\text {-eng.cfm }}$

Statistics Canada. (2017b). Nunavut [Territory] and Canada [Country]. https://www12.statcan.gc.ca/census-recensement/2016/dp-pd/prof/details/Page. cfm?Lang $=\mathrm{E} \& \mathrm{Geo} 1=\mathrm{PR} \&$ Code $1=62 \& \mathrm{Geo} 2=\& \mathrm{Code} 2=\&$ SearchText $=$ Nunavut $\underline{\& \text { SearchType }=\text { Begins } \& \text { SearchPR }=01 \& \mathrm{~B} 1=\text { All } \& \text { GeoLevel }=\text { PR } \& \text { GeoCode }=}$ $\underline{62 \& \text { type }=0}$

Truth and Reconciliation Commission of Canada. (2015). Canada's residential schools: The Inuit and Northern experience. (Vol. 2). McGill-Queen's University Press. http://www.trc.ca/assets/pdf/Volume_2 Inuit and Northern_English_Web.pdf 
Walton, F., McAuley, A., Sandiford, M., Trumper, K., Miller, T., Preston, J., Lea, G., O’Leary, D., Arnaquq, N., McGregor, H., Lee, C., Mearns, R., Wheatley, K., Eegeesiak, N., Hainnu, J., \& Flaherty, L. (2014). Inuit Qaujimajatuqangit and the transformation of high school. Université Laval. https://arcticnet.ulaval.ca/docs/ high_school education_2013-14.pdf

Wenzel, G. W. (1995). Ningiqtuq: Resource sharing and generalized reciprocity in Clyde River, Nunavut. Arctic Anthropology, 32(2), 43-60. https://www.jstor.org/ stable $/ 40316386$ ? seq $=1$ \#metadata info tab contents

Wheatley, K., Tulloch, S., \& Walton, F. (2015). "We are building a critical voice together": The second Nunavut Master of Education Program, 2010-2013. Government of Nunavut, Department of Education. https://projects.upei.ca/ nunavut/files/2015/03/We are Building_a_critical_voice together 2015 Wheatley.pdf 